\title{
18th Radiochemical conference: RadChem 2018
}

\author{
Mariánské Lázně, 13-18th May 2018
}

\section{Mojmír Němec $^{1} \cdot$ Jiří Mizera $^{2} \cdot$ Jan John $^{1} \cdot$ Jan Kučera $^{2}$}

Published online: 12 November 2018

C Akadémiai Kiadó, Budapest, Hungary 2018

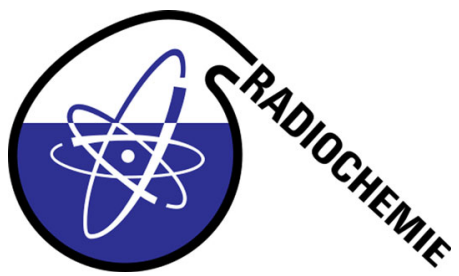

The 18th Radiochemical Conference-RadChem 2018, was held in the Casino conference centre in Mariánské Lázně, Czech Republic, on the 13-18th May 2018. As usual, the conference was co-organized by the Czech Chemical Society, Ioannes Marcus Marci Spectroscopic Society, and Department of Nuclear Chemistry, Faculty of Nuclear Sciences and Physical Engineering, Czech Technical University in Prague (DNC FNSPE CTU). Since 2010, the RadChem series has been organised on behalf of the Division of Nuclear and Radiochemistry of the European Chemical Society (DNRC EuChemS)-earlier the European Association for Chemical and Molecular Sciences.

\section{EuChems \\ European Chemical Society}

Traditionally, RadChem 2018 was organised in cooperation with the International Atomic Energy Agency (IAEA) and was sponsored by the International Union of Pure and Applied Chemistry (IUPAC).

Since the previous conference, the number of participants increased again-RadChem 2018 was attended by 334 participants from 36 countries from all parts of the

Mojmír Němec

mojmir.nemec@fjfi.cvut.cz

1 Department of Nuclear Chemistry, FNSPE, Czech Technical University in Prague, Prague, Czech Republic

2 Nuclear Physics Institute, Academy of Sciences of the Czech Republic, Řež, Czech Republic

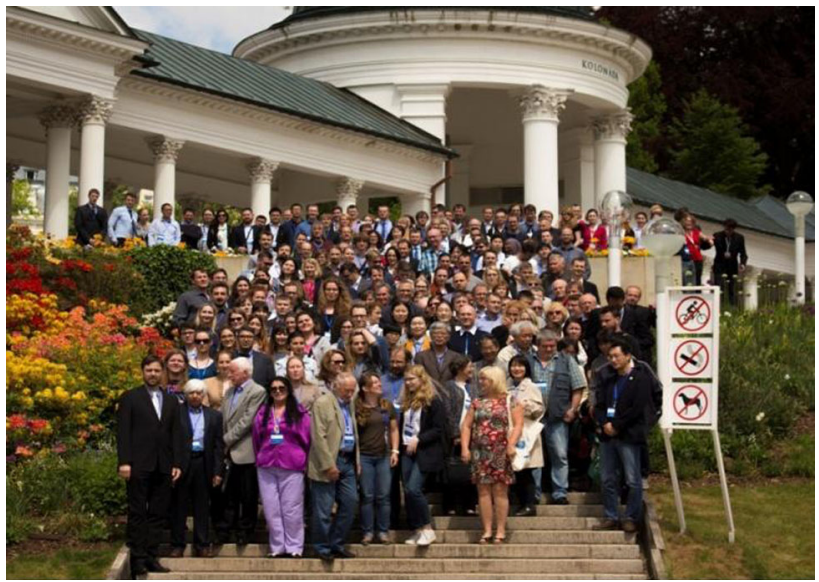

world, from which the most represented countries were the Czech Republic, Germany, Russia, China, France Japan and Slovakia. A new feature for RadChem series was the large number of Chinese participants (18) and significantly increased French representation (17). Compared to RadChem 2014, the number of US and Canadian participants slightly decreased-probably due to the proximity in time of RadChem 2018 and MARC XI (Hawaii, 8-13th April 2018). In total, 356 contributions were presented at the meeting - 157 lectures, including 7 plenary and 14 invited, and 199 posters. The scientific programme was accomplished, except for the plenary lectures, in two parallel sessions. The programme of most of the sessions was opened with invited lectures. The poster presentations were organised into topical sessions and spread over 3 days to give the participants ample time for the discussion with the authors. 
RadChem 2018 was honoured by being selected as the host of the celebration of the 50th anniversary of the Journal of Radioanalytical and Nuclear Chemistry. The anniversary was commemorated in a lecture "Fifty years of the Journal of Radioanalytical and Nuclear Chemistry" delivered by JRNC editor, dr. Zsolt Révay, during the Sunday evening opening session. The conference itself covered most of the topical issues in the field of nuclearand radiochemistry in a total of nine sessions including:

\begin{tabular}{|c|c|}
\hline Session & Organisers \\
\hline $\begin{array}{l}\text { Radionuclides in the environment } \\
\text { and radioecology }\end{array}$ & $\begin{array}{l}\text { Pavel P. Povinec, } \\
\text { Stepan N. Kalmykov, } \\
\text { Michal Fejgl }\end{array}$ \\
\hline Nuclear analytical methods & $\begin{array}{l}\text { Xiaolin Hou, Jan Kučera, } \\
\text { Jan Kameník }\end{array}$ \\
\hline $\begin{array}{l}\text { Chemistry of actinide and trans- } \\
\text { actinide elements }\end{array}$ & $\begin{array}{l}\text { Andreas Türler, Ladislav } \\
\text { Havela }\end{array}$ \\
\hline Radiation chemistry & $\begin{array}{l}\text { Simon M. Pimblott, Václav } \\
\text { Čuba, Vít Plaček }\end{array}$ \\
\hline $\begin{array}{l}\text { Production and application of } \\
\text { radionuclides }\end{array}$ & Jiří Mizera \\
\hline Separation methods and speciation & Andreas Geist, Mojmír Němec \\
\hline $\begin{array}{l}\text { Chemistry of nuclear fuel cycle and } \\
\text { radiochemical problems in nuclear } \\
\text { waste management }\end{array}$ & $\begin{array}{l}\text { Christian Ekberg, Václava } \\
\text { Havlová }\end{array}$ \\
\hline $\begin{array}{l}\text { Radiopharmaceutical chemistry and } \\
\text { labelled compounds }\end{array}$ & $\begin{array}{l}\text { Constantin Mamat, Ondřej } \\
\text { Lebeda }\end{array}$ \\
\hline Education & Clemens Walther, Jan John \\
\hline
\end{tabular}

Here we would like to thank all the Session Organisers and to the International Advisory Board for their help and support in RadChem 2018 organisation.

The full conference programme is available at the conference web page (http://www.radchem.cz), the booklet of all accepted abstracts was published as a special issueVol 16, No 2 (2018)—of the journal Czech Chemical Society Symposium Series and is available (open access) at http://www.ccsss.cz/index.php/ccsss/issue/viewIssue/14/

30. Full texts of the contributions that have been selected based on the results of a standard double-blind peer-review procedure and are collected in this special issue of the Journal of Radioanalytical and Nuclear Chemistry.

Two prestigious scientific awards were presented during the block of the opening plenary lectures. The first was the Ioannes Marcus Marci Medal for excellence in and significant contribution to spectroscopy established in 1977 by the Ioannes Marcus Marci Spectroscopic Society and named after Ioannes Marcus Marci from Kronland, a prominent renaissance Czech scientist, physician and academic dignitary of Charles University $(* 13.6 .1595, \uparrow 10$.

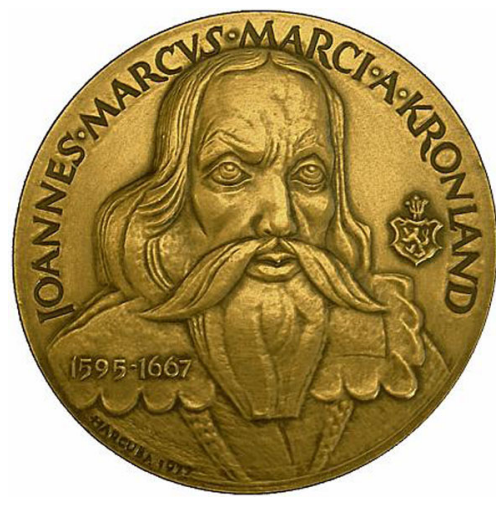

4. 1667). The medal was awarded to Prof. Peter Bode (Delft University of Technology, The Netherlands) in recognition of his excellent results in the field of instrumental radioanalytical methods, especially neutron activation analysis, and in chemical metrology. Prof. Bode delivered a laurate lecture on the topic „Quo Vadis, neutron activation analysis?"

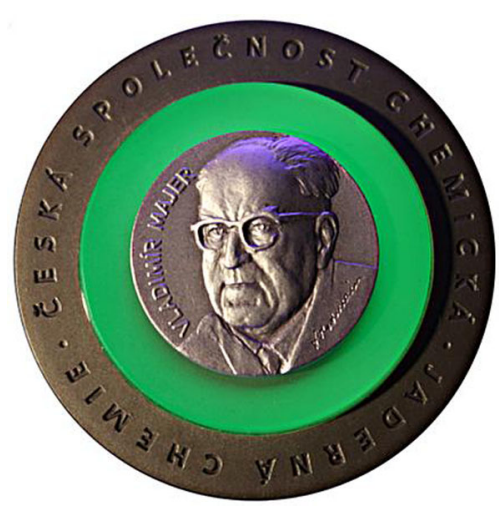

The second appraisement was the Vladimír Majer Medal Award. Vladimir Majer Medal Award is presented by the Nuclear Chemistry working group of the Czech Chemical Society to scientists who significantly contributed to the development of nuclear chemistry or played a decisive role in the development of some of its branches. The medal is named after Prof. Dr. Vladimír Majer (*19. 3. 1903, †5. 7. 1998), a prominent Czech nuclear and physical chemist, one of the pioneers of the Czech radiochemistry. The 2018 medal was awarded to Prof. Jukka Kalevi Lehto, $(* 1.10$. 1953) head of the Head of the Laboratory of Radiochemistry at the Department of Chemistry, University of Helsinki, Finland. Prof. Lehto is internationally one of the leading radiochemists and an active member of the international radiochemistry society. He was awarded the Vladimír Majer Medal in recognition of his international contributions to ion exchanger development for radioactive 
waste treatment and investigation of geological and environmental behaviour of radionuclides.

Every day after the demanding conference scientific programme, the participants could have enjoyed a rich social and cultural programme. Besides the Welcome Reception celebrating the 50th Anniversary of JRNC on Sunday mentioned above, every evening played its specific role. The Beer Party on Monday evening presenting Czech cuisine and selection of local beers was well appreciated by participants. Undoubtedly, the cultural peak of this week social programme was the Tuesday night concert of Jiří Pavlica's Hradišt' an Dulcimer Band (http://www.hradistan. cz/en) - one of the oldest and most well-known Moravian dulcimer bands. Traditionally, Wednesday afternoon was dedicated to trips to historical monuments and nature beauties of the surroundings of Mariánské Lázně. Depending on the selected trip, the participants visited Karlovy Vary, Moser glassworks, Thun china factory, Loket medieval castle, SOOS nature reserve, Kynžvart chateau, Chodovar brewery, and Teplá monastery, where all the groups met in the evening for a joint celebration dinner. On Thursday evening, an amateur musician group composed of the conference participants presented a folkrock programme rehearsed on-site during the conferencethis was a second time that this RadChem 2014 successful musical experiment took place and clearly marked a start of a new tradition at RadChem conferences. Traditionally, the last of the social events was the Thursday night Singing Fountain performance at the spa colonnade. 